\title{
Unethical and Socially Irresponsible Behaviour in the Marketing of Goods and Services in Nigeria
}

\author{
${ }^{1}$ Nwodo Sylvanus I., ${ }^{2}$ Okolo, Victor O., ${ }^{3}$ Ugonna, Ikechukwu A., and ${ }^{4}$ Nebo, Gerald N. \\ ${ }^{1}$ Department of Marketing, Federal University of Agriculture, Umudike \\ ${ }^{2}$ Department of Marketing, University of Nigeria, Nsukka \\ ${ }^{3}$ Department of Marketing, Chukwuemeka Odumegwu Ojukwu University, Uli \\ ${ }^{4}$ Department of Marketing, Enugu State University of Science and Technology, Enugu, Nigeria
}

\begin{abstract}
Marketing, more than any other business activity, deals with members of the society. As a social activity, it generates various kinds of responses from different segment of the society. Because of the considerable impact which it has on our lives, virtually everybody has something uncomplimentary to say about marketing. The focus of this paper is on the impact of product unethical and socially irresponsible behaviours on society. The objective of the paper is to identify and analyze the unethical and socially irresponsible behaviours associated with product. This paper, indeed, examines very critically the product unethical and socially irresponsible behaviours and associated criticisms levelled against marketers. The paper highlights the product unethical behaviour and criticisms and makes suggestions which seek to stop or reduce drastically such unethical manifestations.
\end{abstract}

Keywords: Unethical behaviour, Ethical Standard, Social Responsibility, Consumerism, Brand Proliferation

\section{INTRODUCTION}

In today's marketing activities, many businesses have devoted more attention to what is called their social responsibilities. There are a lot said about such obligation but viewpoints differ as to what constitutes the firm's social responsibilities. Some scholars argue that the responsibility of business is to make profit. By doing so, the society benefits and peoples' material needs are met. However, other scholars are of the opinion that the responsibility of a business is to satisfy the society. The firm belongs to the people and thus has an obligation to the different sections of the society- suppliers, consumers, stock brokers, employees, local community, government and the general public (Obiessie 2003).The social responsibility of business is a logical extension of the societal marketing concept and social marketing (Adirika, Ebue and Nnolim, 2001).

In recent years, a lot of question about marketing practices have been asked. Many people argue that marketing is not being practiced the way it should be. They maintain that existence of consumerism is an evidence of this fact. In their opinion, the marketing concept is not being practiced by many business firms. Even in situation where firms satisfy consumer wants and interest, the long-run interest of the society may be dissatisfied. For example, in the effort of a company to satisfy consumer wants for automobiles, questions can be asked about the uncovered social costs of heavy pollution, road accidents, and high maintenance cost that will result with automobiles (McCarthy 1968). This situation has created more pressure for social marketing and has led to the development of the societal marketing concept, which focuses on long run consumers' and society's well being. Social responsibility is the responsiveness of the society. It is carrying out the moral obligation of business to the society (Onah and Thomas, 2004).

Marketers' social responsibilities flow out of their conception of business ethics. Ethics have to do with the principles and values that govern the actions and decisions of individuals or groups. They are called marketing ethics when these actions and decisions concern marketing activities. Values refer to the beliefs about what is right and wrong and what is important in life (Anyanwu, 2013). Smith (2009) defined marketing ethics as ethical standards which pertain to marketing. Nnabuko (1998) saw marketing ethics as the area of applied ethics which deals with the moral principles behind the operation and regulation of marketing. He also observed that marketing ethnics covers the following framework: 
> Values oriented framework which analyzes ethical problems on the basis of the values which they infringe e.g, honesty, transparency, privacy etc.

Stakeholders oriented framework which analyzes ethical problems on the basis of whom they affect e.g, consumers employees, society, competitors etc.

$>$ Process oriented framework which analyzes ethical problems on the basis of the categories used by marketing specialists e.g., research, price, promotion, product, distribution, etc.

\section{ETHICAL STANDARD}

a. The ethics of business are changing and can never be generalized. They are influenced by many factors in the society. The ethical standards tend to be higher when the following factors are present in the society (Busch and Houston, 1985).

b. Public disclosure, publicity, media coverage and better communication

c. Increased public concern, public awareness, better informed public and societal pressures and social expectation for the role of business.

d. Government regulation, legislation and intervention.

e. Greater sense of social responsibility and greater awareness of its implication by businesses.

f. On the other hand, the ethical standards will be lower when the following factors are present in the society.

g. Low societal standards, social decay, more permissive society, materialism and hedonism, loss of church and home influences

h. Competition, search to succeed poor economic conditions and high cost of doing business.

i. Political corruption, loss of confidence in government.

j. Greed, desire for gain, worship of wealth as a measure of success, individual selfishness, lack of personal integrity and moral fibre.

k. Pressure for profit from within the organization, from shareholders, board members and the executives.

\section{AREAS Of Social RESPONSIBILITy}

The role of business is to act within the framework established by ethics and by government to satisfy the demands of the public. Guided by this framework, more and more businesses are becoming increasingly more socially responsible. The concept of corporate social responsibility had been existing and therefore no longer new (Okolo and Agu, 2015). Social responsibility enables a firm to be in the good books of consuming public. It increases consumer well-being and promote the general welfare of the public. Failure to perform social responsibility will not only put a firm in the disfavour of the society, but also attract government control, scrutiny and regulations to protect the consumers and the general public (Cannon, 1999).

Social scientists have presented different lists of what constitutes areas of social responsibility.

1. Increasing the efficiency of marketing operations, so as to lower distribution cost and selling prices.

2. Properly interpreting and anticipating consumer demand

3. Refusing to do business with unethical suppliers

4. Reducing the marketing problems of low income consumers

5. Increasing product safety

6. Minimizing defective products

7. Developing more informative packaging and labelling

8. Supporting consumer education

9. Supporting the cause of social justice

10. Reducing environmental pollution and hazards

11. Maximizing long-run profits

12. Maximizing job content and satisfaction for the workers 
13. Participating in community welfare and improvement

14. Efficient (or economic) use of energy and natural resources

15. Removing all forms of discrimination against women, old people and minority groups.

16. Instituting a programme for hiring and training the disadvantaged and the unemployed.

\section{Consumerism}

When marketing fails to live up to its ethical and social responsibilities to both consumers and the society, the result is consumerism. Consumers generally expect and demand fair treatment in the market place. Today's consumer is more affluent, better educated, more sophisticated and probably more aware (Palmer, 2001). These characteristics result in an insistence that they be treated fairly. When they are not, there is individual or group reaction to seek redress. This reaction or agitation is what is referred to as consumerism.

Adebayo (1980) stated that consumerism is caused by discontent that results from an abuse of the buyers rights. These rights which were first identified in 1962 by President John F. Kennedy of America include:

\section{$>$ The Right to Safety}

To be protected against marketing questionable products - products that may be hazardous to health or life.

\section{$>$ The Right to be Informed}

To be protected against fraudulent deceitful or grossly misleading information advertising, labelling or other practices and to be given the facts needed to an informed choice.

\section{$>$ The Right to Choose}

To have access to a variety of products satisfactory quality and services at fair price.

\section{$>$ The Right to be Heard}

To be assure that consumers interest will be given full and sympathetic consideration in the formulation of government policy.

\section{EMERGENCE OF ETHICAL AND SOCIAL RESPONSIBILITY IN BUSINESS}

Ethical and social responsibilities emerged as important concepts in business around the early 1950s (Spratlen, 1986). The significant expression of concern for social responsibility in marketing did not occur until the mid 1960s, going by the increased number of articles on that issue from this period upwards.

Prior to adoption of the modern marketing concept, a lot of vices were being committed by businesses leading to marketing malpractices. After the second world war of 1945, business people felt the need to embrace the modern or simple marketing concept and in doing this, they relegated the long-term interest of the society to the background. They felt their job was to satisfy their consumers and generate profits for the organization.

Until the 1960s, raw materials and resources for productive activities were considered limitless, so nobody cared about conservation of resources and deterioration of the environment and waste of resources - responsibility for the general public was given a back seat. Thus, a few conscientious executives listened and thought seriously about the raised issues and sooner ethical and social responsibilities were added to the stockpile of capitalism (Okeke, 1993).

Nwokoye (1984) summarised the reasons for the emergence of ethical and social responsibilities in business as shown below:

- To reverse the declining public confidence in business, resulting from a lot of bad and unorthodox practices and lack of regard for the welfare of the larger society.

- To pay the price of economic freedom, which definitely leads to social problems which affect not only the firm and its customers but also the society at large. It is therefore in the interest of business to attend to these problems.

- To balance the power responsibility equation. Marketers wield and exert a great deal of influence on consumers and the economic policy of nation and are expected to show responsibility commensurate with the power. 
- To enable the marketing department represent the company very well and so resent a god corporate image before the customers and the public at large.

\section{SIGNS OF UNETHICAL AND SOCIALLY IRRESPONSIBLE BEHAVIOUR}

It is simple to say that once a behaviour is against acceptable business and social norms, it is unethical and socially irresponsible (Adirika, 1998) Marketers/salespersons should watch their behaviours if

- Customers complain against such behaviour

- The company is not happy with the behaviour

- It causes ripples in professional circles

- It causes increased customers and or society resistance.

- It leads to warnings and or sanctions from the company, professional bodies or government

- It leads to protests and boycott of the company products by the consumers

- It increases or causes an uncomfortable level of consumer activism or consumerism

The list is not exhaustive, but marketer/sales persons must do all that is possible to avoid acts or behaviours that can be interpreted as unethical or socially irresponsible.

\section{CONSEQUENCES OF UNETHICAL AND SOCIALly IRRESPONSIBLE BEHAVIOUR}

Marketers/salespersons should bear this saying in mind. A dissatisfied customer is like the Indian elephant, he never forgets his dissatisfaction. Dissatisfied customer are like a herd of elephants on rampage, and a dissatisfied society is like an organised body of elephants on the war path (Adirika, 1997).

This means that consequences of serious dissatisfaction on the part of the customer, consumers and the society at large are better imagined than experienced. Salesperson must remember that marketing cannot survive without two factors:

- Customer attraction and

- Customer retention

However, customer retention is more critical than customer attraction. That is why we say that marketing survives on the Oliver Twist syndrome, "Always asking for more" (Adirika, 1997) Kotler and Armstrong (2010) summarised the consequences of unethical and socially irresponsible behaviour of salesperson or marketers as follows:-

- Dissatisfied customers or consumers

- Dissatisfied society and government

- Loss of business

- Loss of market share

- Damage to company's image

- Loss of goodwill

- Increase in consumerism or consumer activism

- Legal actions

- Sanctions

- Possible business failure

\section{Unethical Behaviours/Practices on Product}

Unethical practices have been traced and reported in all the functional areas of business. The production, finance and accounts, administration, personnel and other functional units of business organisations have traces of unethical practices. The marketing unit or field, however, seems to have a fair share of it (Smith, 2001). Walker and Stanton (1975) had observed that marketers are responsible 
to a variety of groups namely customers who depend on them for need satisfaction; employers with sales and profit expectation; supplier and distributors anticipating continuity of business relations and the society which expects them to be responsible citizens. The divergent interests of these groups create a wide variety of ethical challenges for marketers.

Kotler and Keller (2009) observed that prior studies have revealed many incidence of unethical practices in marketing research, selling, advertising, product and promotion. The widespread of unethical marketing practices by marketing practitioners as a means of achieving organisational goals and also to cope with the harsh business environment demands urgent attention. In marketing, each of the four Ps raises ethical questions and these have been articulated by Babbie (1986). What responsibilities do producers have for the quality and safety of their products? Who is responsible for harms caused by a product? Are there some products that should not be produced, or does consumer demand decide all production questions? Bartels (1968) had observed that most of the unethical behaviours by marketers - adulteration of goods, exaggerated advertisements, misleading adverts, hoarding, predatory pricing, etc have their foundation on the undue desire to make huge profits. In the desire of some of the marketers to increase their profit margins, they embark on series of unethical behaviours to the detriment of the consumers.

Agbonifoh, Ogwo, Nnolim and Nkamnebe (2007) observed that critics of marketing are quick to point to perceived inadequacies in some of the product policies pursued by many business organisations. These criticisms, in a nutshell relate to the following:

- Excessive brand proliferation

- Non-progressive planned obsolescence

- Sale of fake, inferior and unsafe products and brands

- Servicing of products

- Dishonoured guarantees

- Neglect of after sales service

- Product diversion

- Adulteration of products

- Exaggeration of product benefits

- Environment

\section{BRAND Proliferation}

This is the bane of free enterprise and free competition in which countless number of companies produce versions of their brand names and brand marks. Almost invariably, each producer claims that his brand is the best. In the face of these claims and counter claims which the average consumer is not in a position to verify or even appreciate, becomes helpless and palpably confused. This is because a single manufacturer may have multiple brands of the same basic product without any clear indication of the differences among them. In Nigeria today, the beer, soft drinks, battery, toilet soap, drug and newspaper industries are victims of excessive brand proliferation.

It is noteworthy that the marketers in their able defence of their actions claim that brand proliferation is advantageous to the consumer in that the ensuring competition tends to force down prices. Second, it is claimed with some measure of justification that a multiplicity of brands offers the consumer the much needed variety and choice.

\section{Planned Obsolescence}

The policy of planned obsolescence is pursued by many companies such as car manufacturers and garment industries. By definition, planned, obsolescence is the practice whereby a company regularly replaces its product with more effective or improved models, thereby rendering earlier versions outmoded. The point of the criticism of planned obsolescence is that it is a waste of the consumer's and society's scarce resources, particularly if new models are not superior to those which they are intended to replace. 
Marketer's response to this criticism is that planned obsolescence serves the needs of consumers who seek change and do not want to be saddled with a product that will last for too long. They also argue that the policy enables producers to make cheap affordable versions available to those who need them while continuous product improvement, which is itself desirable, is embarked upon to enable consumer to enjoy the benefits of improvements in technology.

\section{Sale of Fake, Inferior and unsafe (Harmful) Products}

A major problem confronting Nigeria consumers today in the health industry is the increasing case of fake or imitation drugs in our markets. The product is completely fake, like somebody selling chalk as drugs, or selling an inferior product as the genuine one. Similarly, many vehicle spare parts are imitative, non-durable and unreliable. Another ugly practice is that some unscrupulous companies deceitfully affix foreign "made in" labels to their locally made goods. For example, a product manufactured in Lagos, Aba or Kaduna is made to carry a "made in England; "made in Italy" or "made in USA" label or some other foreign label simply because it is known or assured that Nigerian consumers prefer foreign made to locally made goods. Some shoe manufactures appear to be guilty of this malpractice.

In the area of inferior products sale, there is a wide belief that foreign products are superior to locally made ones in many respects. Those who share this view are quick to point to alleged differences between locally - assembled cars and their imported counterparts, match sticks that would not ignite, electric bulbs that do not light for more than few days and the ball-point pens that do not write etc. One defence, which marketers put up in the face of this criticism, is that other professions also have their Judas Iscariots, their own unscrupulous colleagues who would do anything for personal gains. However, Nigeria as a developing country, cannot be expected to develop and produce overnight products whose quality is equal to or better than, those of goods produced in technologically more advanced countries. The point needs to be made emphatically that this is no excuse for faking or for product adulteration and the sale of expired drugs. In Nigeria, the Federal Ministry of Health has banned the sale of toilet sops with a dangerous level of mercuric iodole or mercury substance in them, but these products are still widely available, and are widely distributed by "sales persons".

\section{DiSHONOURED GuARANTEES}

Many consumers do not have any confidence in most guarantees, whether offered by producers or by middlemen. There are incessant complaints regarding the poor quality services offered by Banks and insurance companies. The general observation is that to cash a cheque on a typical day in some commercial banks could take anything upwards of thirty minutes and sometimes hours unless the customer concerned has friends or relations across the counter. It is also widely believed that insurance companies invent all kinds of excuses and conditions to circumvent the payment of genuine insurance claims. Banks and insurance companies offer the plausible excuse that delays arise because the alleged high level of dishonesty in our society demands that cheques, bank drafts and insurance claims be thoroughly scrutinised and verified before they are settled. They argue that this measure is to safeguard both the customer and the company.

\section{Neglecting AfTer - SAles Service}

Marketers are accused of neglecting after sales service, which is a vital function of the marketer. Once goods have been sold, so the argument goes, the marketer is indifferent to the problems which the buyer encounters in its usage. Quite often, spare parts are hard to come by as in the case of many brands of American and Japanese cars and electronics. Reliable repair service shops are rare or where made available by the producer or his middlemen, the charges are prohibitive.

In their own defence, marketers blame the non-availability of spare parts on government's import restriction measures while the high cost of repair and maintenance services is attributed to the cost of spare parts and of training and maintaining a dependable repair and maintenance crew.

\section{Product Diversion}

Marketers are accused of diverting of products meant for a buyer to another destination. The tanker drivers, in collusion with depot officers or "salespersons" are masters of this evil practice especially, during petroleum products scarcity. 


\section{Adulteration of Produce}

Some unscrupulous "salesperson" in their bid to make money, adulterate their products or encourage adulteration. It is not unusual to hear of person adding sand-dust to fertilizers, or kerosene to petrol. In other instances, genuine products are adulterated by middlemen so as to increase their profits. This problem became so serious in the petroleum industry that the Buhari Administration had to promulgate a decree banning roadside unregistered dealers from the marketing of petroleum products.

\section{Exaggeration of Product Benefits}

It is not uncommon to hear the "quick-made" sales persons claiming that a product can perform wonders, claims that can never be verified or substantiated. These sales person hop from one bus to another, or ride on trains, or stay at motor parts and street corners claiming that one drug can cure a thousand but one diseases. If a customer is unfortunate enough to buy these drugs, the customer ends up getting no cure or worse still, having the illness worsened. This over-exaggeration creates problems for genuine drugs and professional salespersons, who happen to come across such customers who have been hurt before.

\section{ENVIRONMENT}

Environment is the milieu in which the company is operating. Within this environment, our competitors are also operating and what they do affects our own behaviour as a company. In adopting the marketing concept, the firm must take its matching orders from the market since its foremost job is to produce what the market needs. The environment in which firms operate is not controlled by them because it is dynamic. The role of marketing is to match the company capabilities with customer wants. This matching process has three constituent parts, namely: (Onah, Ndolo and Allison, 2006).

- The capabilities of a firm

- The wants of customers

- The marketing environment

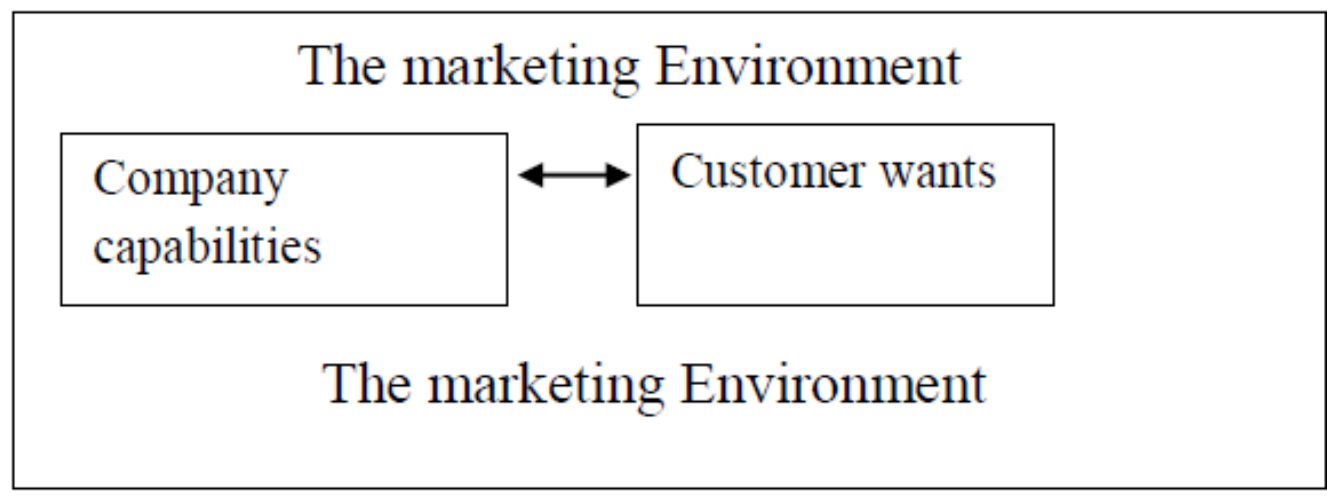

FigureI. The matching process of marketing

Source: M.H.B. McDonald marketing plans, P.3

Matching company's capabilities with the customers' wants must be a dual process. That is, customer's wants affect and influence the company's capabilities. The company on its part must produce what the customer wants. When this condition is not met, then the company must go back and review its capabilities in order to give the customer what she wants.

Critiques often accuse companies of producing what customers do not need. They do not take into account the legal, economic, political, traditional, religions and fiscal policies of the government of the country where they operate, in their marketing plans. This results to a situation where many products launch fail.

\section{SUGGESTIONS/RECOMMENDATIONS}

The product related criticisms condemn brand proliferation, planned obsolescence, imitative and unreliable products, fake labels, adulteration of products and dishonoured guarantees, among others. It is, therefore, expected that marketers, consumers, consumer organisations and the government in particular will take steps urgently to remedy the situation. 
a. Government should respond to the plight of consumers by enacting protective legislation and providing consumer education.

b. Organizations should establish a department of social affairs to be charged with the responsibility of formulating and implementing the firm's social responsibility policy and programmes and also monitor the impact of the firms ethical and social responsibility programmes on its customers, the company itself and the society at large.

c. Marketers should attempt to check their own excesses by adopting the principle of societal marketing and social responsibility in their business conduct.

d. Consumers, on their own, should organize themselves into consumer associations in order to protect and promote their collective interests.

e. Marketers should be re-oriented on the need for proper behaviour and restrained from unethical behavioru by reminding them of relevant sanctions, whilst letting them known the need to fulfil their moral obligations, and letting them know the joy, reward and satisfaction inherent in such behaviour.

f. A well articulated company policy on ethics should be developed and circulated to marketers for their perusal and guidance (Laczniak (1986) advocates a number of them as follows:-

- The Golden Rule: Act in the way you would expect others to act towards you.

- The Utilitarian Principle: Act in the ways that result in the greatest good for the greatest number.

- The Professional Ethics: Take only actions, which would be viewed as proper by a disinterested panel of professional colleagues.

g. Embark on appropriate public relations campaigns to correct or remove the bad image and loss of goodwill caused by marketers' unethical and socially irresponsible behaviours.

h. A company must monitor the elements of the environment and adapt to or change in order to reap the full benefits accruing from its target market. Failure to understand the needs and wants of different customers or groups would result in failure to provide the desired satisfaction, and on the long-run collapse of the company due to non-patronage.

\section{Conclusion}

As a social activity, marketing generates various kinds of responses from different segment of society. Because of the considerable impact which it has on our lives, virtually everybody has something uncomplimentary to say about marketing.

There are thus many product related criticisms. Generally, marketers have responded to these criticism. In some cases, they blame the bad eggs in their midst as in the case of adulterated products and misleading advertisement. In some other cases, the practice are said to be in the interest of consumers. Cases in point are brand proliferation and planned obsolescence. There is a great deal of truth in the arguments of critics, at least, as far as product related unethical behaviours in Nigeria is concerned.

\section{REFERENCES}

[1] Adebayo, A. (1980) "The Relevance of Consumerism for a Developing Economy". Nigerian Journal of Marketing, 6(2): 44-51.

[2] Adirika, E.O, Ebue, B.C. and Nnolim, D.A. (2000) Principles and Practice of Marketing One, Enugu- Nigeria: John Jacob classic publishers Ltd.

[3] Adirika, E.O. (1998) Professional Selling. Enugu-Nigeria: Optimal Publishers

[4] Anyanwu, A. (2013) Marketing Management and Strategy Owerri: Avan Global Publications.

[5] Babbie, E. (1986) the Practice of Social Research. Belmont-California: Weds worth Publishing co.

[6] Bartels, R. (1968) "The General Theory of Marketing” Journal of Marketing 32(1):4-6.

[7] Busch, P.S. and Houston, M.J. (1985) Marketing Strategic Foundations, Homewood Illionis: Richard D. Irwin Inc.

[8] Cannon, T. (1999) Basic Marketing, London: Casell publisher. 
[9] Kotler, P. and Armstrong, G. ((2010) Principles of Marketing. New Jersey: Pearson Prentice Ltd.

[10] Kotler, P. and Keller, K.L. (2009) Marketing Management. New Jersey: Pearson Prentice Hall.

[11] Laczniak, G.R. (1986) Framework for Analyzing Marketing Ethics, Cincinnati: South Western Publishing Co.

[12] McCarthy, E.J. (1968) Basic Marketing a Managerial Approach, Homewood Illinios: Richard D. Irwin Inc.

[13] Nnabuko, J. (1998) Marketing Management, Enugu Precision Printers and Publishers.

[14] Nwokoye, N.G. (1984) Modern Marketing in Nigeria, London: The Macmillan Press limited.

[15] Obiesie, M.C. (2003) Marketing Management: A Theoretical and Practical Approach. Enugu: John Jacobs classical publishers Ltd.

[16] Okeke, C.I. (1993) Modern Salesmanship and Sales Management, Enugu.Akuezu-Mkpa Books.

[17] Okolo, V.O. and Agu, O.A. (2015) "Importance of Marketing Research in Improving Corporate Social Responsibility (CSR) Adopted by Seven Up in Enugu "International Journal of Development Research Vol. 5 , Issue, 05

[18] Onah, J.O. and Thomas, M.J. (2004) Marketing Management: Strategies and Cases. Enugu: Institute for Development Studies.

[19] Onah, J.O., Ndolo, I .S. and Allison, P.U. (2006) Marketing and Management Practice in Nigeria. Enugu- Nigeria: African Marketing Development foundation.

[20] Palmer, A. (2001) Principles of Services Marketing, London: McGraw-Hill

[21] Smith, M.D. (2009) Fundamentals of Marketing. Japan: McGraw-Hill Inc.

[22] Spratlen, T.A. (1986) Marketing: A Social Responsibility, Cincinnati: South Western publishing company. 